\title{
Arginine Supplementation in Patients Diagnosed with Drug-sensitive Pulmonary Tuberculosis
}

\author{
Paula Victoria Catherine Y. Cheng, ${ }^{1}$ Paolo Nikolai H. So, ${ }^{1}$ Rogelio N. Velasco, Jr. ${ }^{1}$ and Norman L. Maghuyop ${ }^{2}$ \\ ${ }^{1}$ Department of Medicine, Philippine General Hospital, University of the Philippines Manila \\ ${ }^{2}$ Section of Pulmonary Medicine, Department of Medicine, College of Medicine and Philippine General Hospital, University of the Philippines Manila
}

\begin{abstract}
Objective. To determine the effects of arginine in the rates of sputum conversion in patients with drug-sensitive pulmonary tuberculosis.

Methods. Studies from PubMed, Medline, EMBASE, and Cochrane were reviewed and appropriate studies were included. Randomized controlled trials comparing arginine with placebo in adult patients with drug-sensitive pulmonary tuberculosis were included. The risk of bias was assessed using the Cochrane Risk of Bias tool. A metaanalysis of the rate of sputum conversion at 8 weeks, was conducted. Post hoc analyses of sputum conversion at 4 weeks, and cough reduction at 4 and 8 weeks were done.
\end{abstract}

Results. Three articles included in this study had a pooled population of 452 participants. This meta-analysis showed no significant difference in the sputum conversion at 4 and 8 weeks, with a relative risk of $0.96(95 \% \mathrm{Cl} 0.77-1.20)$ and 1.07 (95\% Cl 0.96-1.19), respectively. However, cough was significantly reduced at 4 and 8 weeks, with subtotal relative risks of $0.91(95 \% \mathrm{Cl} 0.82-1.00)$ and $0.43(95 \% \mathrm{Cl} 0.22-0.81)$, and a total relative risk for cough reduction of 0.83 (95\% Cl 0.73-0.93).

Conclusion. While arginine may not significantly reduce sputum conversion rates, it may be used as an adjunct to decrease cough in patients with tuberculosis.

Key Words: arginine, pulmonary tuberculosis, sputum conversion

Poster presented at the 2016 PGH Research forum, November 2016.

Corresponding author: Paula Victoria Catherine Y. Cheng, MD Department of Medicine

Philippine General Hospital

University of the Philippines Manila

Taft Avenue, Ermita, Manila 1000 Philippines

Telephone: +6320922 8320618

Email: pvc.cheng@gmail.com

\section{INTRODUCTION}

\section{Description of the condition}

Tuberculosis is an infection caused by the bacteria Mycobacterium tuberculosis and is an important cause of mortality worldwide. In 2014, the World Health Organization (WHO) reported an estimated 9.6 million incident cases of tuberculosis (TB) around the world, equivalent to 133 cases per 100000 population. In the Philippines, prevalence of TB is estimated at 410,000, incidence at 290,000, and mortalities at 10,000 (Global Tuberculosis Report, 2015). Currently, it is recommended that the standard regimen (comprised of isoniazid, rifampicin, pyrazinamide and ethambutol for two months and isoniazid and rifampicin for four months) against TB should be given for at least six months.

\section{Description of the intervention}

Several food supplements have already been studied in the past to determine their efficacy as adjunctive treatment for patients with tuberculosis. ${ }^{1}$ One such supplement is $\mathrm{L}$-arginine, which is the sole biological precursor of nitric oxide (NO). In macrophages, arginine is converted by nitric 
oxide synthase 2 (NOS2) to NO, concentrations of which correlate with the inhibition of TB bacilli2,3 and the immune response related to it. ${ }^{2}$

NO directly affects $M$ tuberculosis by damaging the cell itself, causing apoptosis of the macrophage. ${ }^{4}$ High levels of $\mathrm{NO}$ are shown in an in vitro study to have bactericidal properties comparable to that of antibiotics. ${ }^{5}$ Low levels of $\mathrm{NO}$, however, are thought to contribute to induction of a non-replicating state for mycobacteria, causing them to be less susceptible to antibiotic treatment. ${ }^{6}$ Thus, appropriate levels of NO are hypothesized to contribute to the faster treatment of tuberculosis.

In a study by Ralph and his colleagues in 2015, they measured the Fractional Exhaled NO (FENO) in patients diagnosed with tuberculosis and corresponding controls. These patients were followed up during their course of treatment and serial measurements of FENO were conducted. At the end of the study, the investigators were able to correlate lower NO levels with more severe forms of the disease and delayed mycobacterial clearance from the culture. Owing to this result, the authors recommended evaluating means which increase pulmonary $\mathrm{NO}$ as an adjunct to $\mathrm{TB}$ treatment.

\section{Significance of the review}

Several studies have already tried to determine the efficacy of adding arginine in the treatment of pulmonary tuberculosis. Findings regarding this adjunctive treatment have been conflicting thus far, with some studies showing benefit. ${ }^{3,7}$ while others showed no net clinical benefit. ${ }^{2,8}$ Hence, the two authors performed a systematic review and meta-analysis to estimate the effect of such micronutrient on TB treatment, mainly measured in the conversion of sputum positive patients on the $8^{\text {th }}$ week of treatment.

\section{Research question}

Among adult patients diagnosed with drug-sensitive pulmonary tuberculosis, how effective is supplementation of arginine to the standard regimen as compared to standard regimen alone (or supplemented with a placebo) in the rates of sputum conversion at 8 weeks of treatment?

\section{OBJECTIVE}

To determine the effect of arginine supplementation in the rates of sputum conversion in patients diagnosed with drug-sensitive pulmonary tuberculosis.

\section{METHODS}

\section{Search strategy}

A systematic search of online/electronic databases such as PubMed, EMBASE, the Cochrane Central Register of Controlled Trials, and other collections of published studies, registries of ongoing clinical trials, and unpublished articles was done to identify all studies and publications which dealt with the effect of arginine in the treatment of tuberculosis. No language restrictions were imposed. All the articles were retrieved online. Search terms comprised of the following: the $\mathrm{MeSH}$ or Medical Subject Headings terms "tuberculosis", "tuberculosis, pulmonary", "Mycobacterium tuberculosis", and "arginine" as well as free text terms "tuberculosis", "pulmonary tuberculosis", "arginine", and "sputum conversion". Review of references of the retrieved articles were conducted to search for other applicable studies. All relevant articles which were retrieved through these search strategies are considered for inclusion in this study.

\section{Selection criteria}

The two authors independently assessed and scanned the titles and abstracts of the retrieved articles and identified those relevant to this systematic review. The following pre-specified inclusion criteria were used for the selection of studies: (1) randomized clinical trials, (2) adult patients diagnosed with drug-sensitive pulmonary tuberculosis, (3) comparison of supplementation of arginine to standard regimen versus standard regimen alone or standard regimen with placebo in the treatment of tuberculosis, and (4) outcomes reported as sputum conversion at 8 weeks of treatment.

\section{Analysis and appraisal of data}

\section{Quality assessment of studies}

The two authors independently assessed the validity of each included trial using Cochrane Collaboration Risk of Bias tool. Validity was determined in terms of the following characteristics: randomization, similarity of baseline characteristics in the treatment groups, allocation concealment, blinding, follow-up rate, and intention-to-treat analysis. Disputes in the assessment of validity were settled by discussion with the consultant co-author. The judgment on each category was classified as either low risk, high risk or with unclear risk for bias. The results of this quality assessment are stated in the results section, under "Assessment of validity".

\section{Extraction of data}

The two authors of this systematic review independently extracted the data using a tailored data extraction form. The following information were gathered: study design, participant characteristics (age, sex, etc), interventions (arginine supplementation: specific formulation and preparation, brand name if any, dosing, duration of treatment), comparison (placebo or none), standard regimen given (dosage and dosing, duration of treatment, etc) and outcome.

\section{Synthesis of data}

The data were analyzed and synthesized using Review Manager 5. For dichotomous data, the relative risk was calculated. Data from each trial included were combined 
Table 1. Characteristics of included studies

\begin{tabular}{|c|c|c|c|c|c|}
\hline Study (year) & Population (N) & Design & Intervention & Outcome & Study quality \\
\hline Farazi (2015) & 68 & $\begin{array}{l}\text { Randomized } \\
\text { controlled } \\
\text { trial }\end{array}$ & $\begin{array}{l}\text { 1. Isoniazid, rifampicin, } \\
\text { pyrazinamide, and ethambutol } \\
\text { for } 2 \text { months } \\
\text { 2. Isoniazid, ethambutol to } \\
6 \text { months } \\
\text { 3. } 1000 \text { mg pure L-arginine } \\
\text { hydrochloride OD for } 30 \text { days }\end{array}$ & $\begin{array}{l}\text { 1. Final treatment success, sputum conversion, } \\
\text { weight gain, and clinical symptoms after } \\
\text { one and two months were considered as } \\
\text { primary outcomes } \\
\text { 2. Secondary outcomes were ESR, CRP, and Hg }\end{array}$ & Good \\
\hline Ralph (2013) & 200 & $\begin{array}{c}\text { Randomized } \\
\text { factorial } \\
\text { trial }\end{array}$ & $\begin{array}{l}\text { 1. HRZE daily for } 2 \text { months } \\
\text { 2. HR thrice weekly for } 4 \text { months } \\
\text { 3. Supplementary L arginine } \\
6 \mathrm{~g} \text { for } 8 \text { weeks, active } \\
\text { cholecalciferol } 50,000 \mathrm{IU} \text { at } \\
\text { baseline and on day } 28 \\
\text { 4. L arginine } 6 \mathrm{~g} \text { for } 8 \text { weeks, } \\
\text { placebo cholecalciferol } \\
\text { 5. }\end{array}$ & $\begin{array}{l}\text { 1. Primary outcome measures were the } \\
\text { proportion of participants with negative } \\
\text { sputum culture on liquid medium at week } \\
\text { 4, and a composite clinical severity score at } \\
\text { week } 8 \text {. The clinical score allocated points } \\
\text { at week } 8 \text { for \%change in weight and FEV1, } \\
\text { cough (worse or same, improved, ceased), } \\
\text { and presence/absence of sputum and } \\
\text { hemoptysis. } \\
\text { 2. Secondary outcomes were safety (death, } \\
\text { hospitalization, hypercalcemia); sputum } \\
\text { smear conversion time (2 consecutive } \\
\text { negative smears without a subsequent } \\
\text { positive); change in 6-minute walk } \\
\text { test, modified St George's Respiratory } \\
\text { Questionnaire, chest radiograph severity } \\
\text { score, \%predicted forced expiratory volume } \\
\text { in one second (FEV1); and primary end } \\
\text { points stratified by HIV status and ethnicity. }\end{array}$ & Good \\
\hline Schon(2003) & 184 & $\begin{array}{c}\text { Randomized } \\
\text { controlled } \\
\text { trial }\end{array}$ & $\begin{array}{l}\text { 1. Isoniazid, pyrazinamide, } \\
\text { rifampicin, and streptomycin } \\
\text { or ethambutol for } 2 \text { months } \\
\text { followed by isoniazid and } \\
\text { ethambutol for } 6 \text { months } \\
\text { 2. } 1 \mathrm{~g} \text { arginine for four weeks }\end{array}$ & $\begin{array}{l}\text { 1. Sputum conversion at Week } 8 \\
\text { 2. Cough at Weeks } 2 \text { and } 8\end{array}$ & Good \\
\hline
\end{tabular}

whenever it was deemed appropriate. A 95\% confidence interval is presented with each result. Heterogeneity of the different trials were determined using the $\mathrm{I}^{2}$ and the chisquare measures of heterogeneity, with a value of $50 \%$ and p-value of less than 0.10 , respectively, to denote significant heterogeneity. The data gathered are presented in a Forrest plot in the results section.

\section{Subgroup analysis}

Post-hoc subgroup analysis was done to compare the following: sputum conversion rates at 4 weeks, and the presence of cough at 4 and 8 weeks.

\section{RESULTS}

\section{Results of the search}

The original search yielded five articles, and these studies were screened by the authors for inclusion in the review. Two studies were excluded, one because it did not deal with supplementation of arginine for the treatment of PTB, and the other because the intervention done was a comparison between low-dose and high-dose arginine, and not comparison of arginine with a placebo drug. A diagrammatic flow chart is shown in Appendix A. For the full details of the excluded studies, please see Appendix B.

\section{Characteristics of included studies}

All three studies included in this meta-analysis were randomized controlled trials comparing the supplementation of arginine versus placebo on top of accepted treatment regimens of pulmonary tuberculosis. For the full details of the included studies, please see Appendix D.

\section{Participants and study sites}

The three trials included a total of 452 participants. All these trials included patients 15-60 years old being treated with active tuberculosis. Farazi et al (2015) conducted the study in Iran while Ralph et al (2013) conducted the study in Imika, Indonesia. Schon et al (2003) conducted the study in Ethiopia. All patients were treated in Directly Observed Treatment Shortcourse facilities in their respective countries.

\section{Interventions}

The interventions in the three trials differed in the amount of arginine supplemented (ranging from $1 \mathrm{~g}$ to $6 \mathrm{~g}$ ) and the duration for which arginine was being given (ranging from 4 weeks to 8 weeks). One study included supplementation of Vitamin $\mathrm{D}$ as an additional intervention. ${ }^{4}$

Table 1 shows a summary of the characteristics of the studies included, and Appendix $\mathrm{C}$ shows a more detailed version of this summary. 
Table 2. Summary of the assessment of validity of the included studies

\begin{tabular}{|c|c|c|c|}
\hline & Farazi 2015 & Ralph 2013 & Schon 2003 \\
\hline Method of random sequence generation (Selection bias) & A & A & A \\
\hline Method of allocation concealment (Selection bias) & A & A & A \\
\hline Incomplete outcome data/Loss of participant to follow up (Attrition bias) & A & C & A \\
\hline Blinding of participants and personnel (Performance bias) & A & A & A \\
\hline Blinding of outcome assessment (Detection bias) & A & B & B \\
\hline Selective reporting/Intention to treat Analysis (Reporting bias) & B & A & A \\
\hline Other bias & NA & NA & NA \\
\hline
\end{tabular}

Legend: A: Low risk, B: Unclear, C: High risk

\section{Assessment of validity}

The risk of bias assessment is summarized in Table 2 .

\section{Allocation}

All three included studies showed an adequate method of randomization. These studies also demonstrated satisfactory methods for preservation of allocation sequence.

\section{Blinding}

All three included studies showed blinding of both the participants and the caregivers. However, only one study showed clear indication of blinding of the outcome assessor. ${ }^{3}$ The authors both deemed that it was unclear whether the outcome assessor was blinded in the remaining two studies.

\section{Incomplete outcome data}

One study was considered at high risk of attrition bias due to the high number of drop-outs. ${ }^{4}$

\section{Selective reporting}

Two out of the three studies reported intention-to-treat analyses and were thus deemed to be at low risk for reporting bias. However, this was not clearly stated in the study by Farazi et al.

\section{Effects of Interventions}

Three studies $3,4,5$ have compared the effect of arginine supplementation in the treatment of pulmonary tuberculosis in terms of sputum conversion. Figure 1 shows the results of the individual studies and the pooled effect of the treatment. The combined risk ratio from three studies is 1.07 (95\% CI 0.96-1.19). Two studies, ${ }^{3,4}$ on the other hand, evaluated sputum conversion at 4 weeks (Figure 2). The risk ratio for the pooled results is 0.96 (95\% CI $0.77-1.20)$.

Several studies also evaluated cough reduction in patients being supplemented with arginine. The overall risk ratio, computed by combining the three studies, was 0.83 (95\% CI 0.73-0.93). Two studies ${ }^{3,4}$ measured cough reduction after a four-week period. The risk ratio was 0.91 (95\% CI 0.82-1.00). Farazi et al. and Schon et al. also measured cough reduction at 8 weeks, with a subtotal risk ratio of 0.43 (95\% CI $0.22-0.81)$. These results are illustrated in Figure 3.

\section{DISCUSSION}

\section{Summary of main results}

\section{Sputum conversion}

The results of pooled analysis showed no significant change in the sputum conversion between the treatment group and the control group. The relative risk of sputum conversion at 4 weeks (RR 0.96, CI 0.77-1.20) is relatively similar to that of the analysis after 8 weeks of treatment (RR 1.07,0.96-1.19). There was no noted significant heterogeneity between the two groups.

\section{Cough reduction}

The available trials showed increased rates of cough reduction both at 4 and 8 weeks of treatment supplemented with arginine, with a more significant improvement shown for the longer time interval. Separately, the analysis for cough reduction at 4 weeks and 8 weeks did not show significant heterogeneity. When pooled together, however, the chi $^{2}$ showed significant $\mathrm{p}$-value of less than $0.10(\mathrm{p}$-value $=0.003$ ) and an $\mathrm{I}^{2}$ of $80.7 \%$, both measures identifying significant heterogeneity. This could be attributed to the difference in the time interval at which cough reduction was assessed.

\section{Overall completeness and applicability of evidence}

The included studies slightly differed in the interventions that they used. Most of them used isoniazid, rifampicin, pyrazinamide, and ethambutol as part of the standard regimen for the first two months of treatment; however, most used isoniazid and ethambutol for the succeeding six months of treatment, while one study used isoniazid and rifampicin thrice weekly for four months. The available trials also varied with the source, dosage, and frequency of administration of their separate arginine supplementation regimens. These differences in the characteristics of the utilized interventions could have accounted for the heterogeneity seen in some of our analyses.

L-arginine supplementation may be available through increasing intake of food rich in arginine such as chocolate, peanuts, coconut, soy beans, almond, dairy products, white flour, and wheat or through intake of L-arginine capsules which are readily available. 


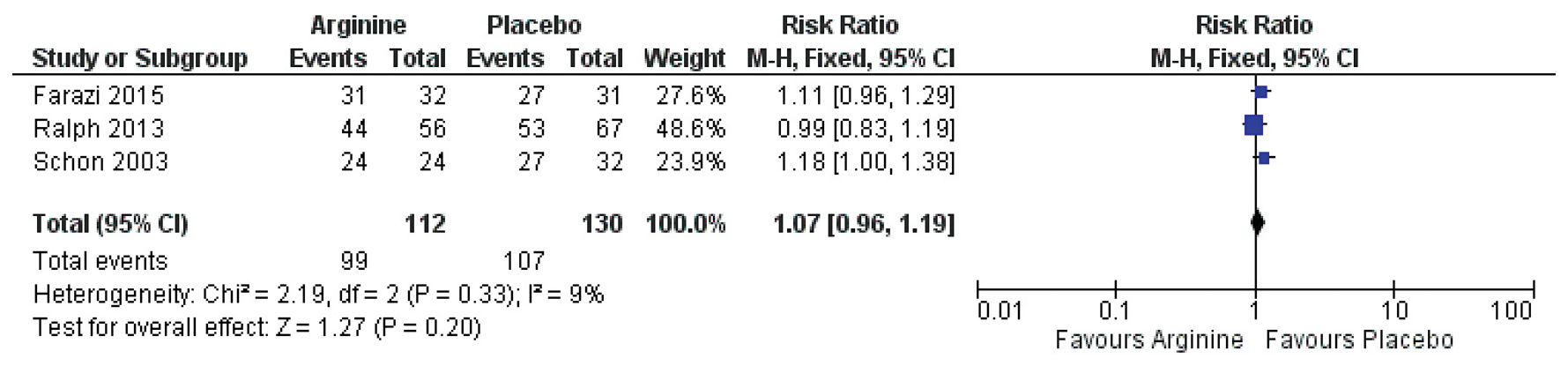

Figure 1. Comparison of arginine and placebo. Outcome 1 sputum conversion at 8 weeks.

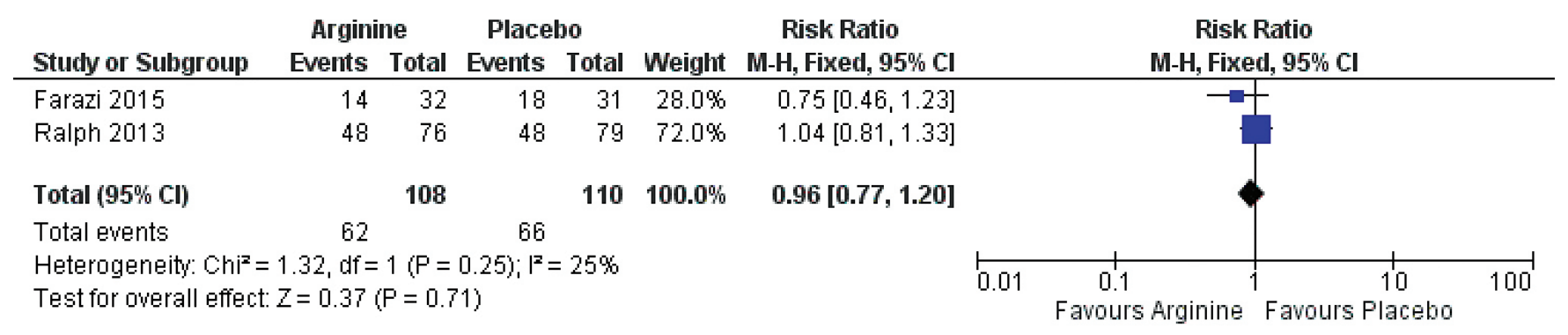

Figure 2. Comparison of arginine and placebo. Outcome 1 sputum conversion at 4 weeks.

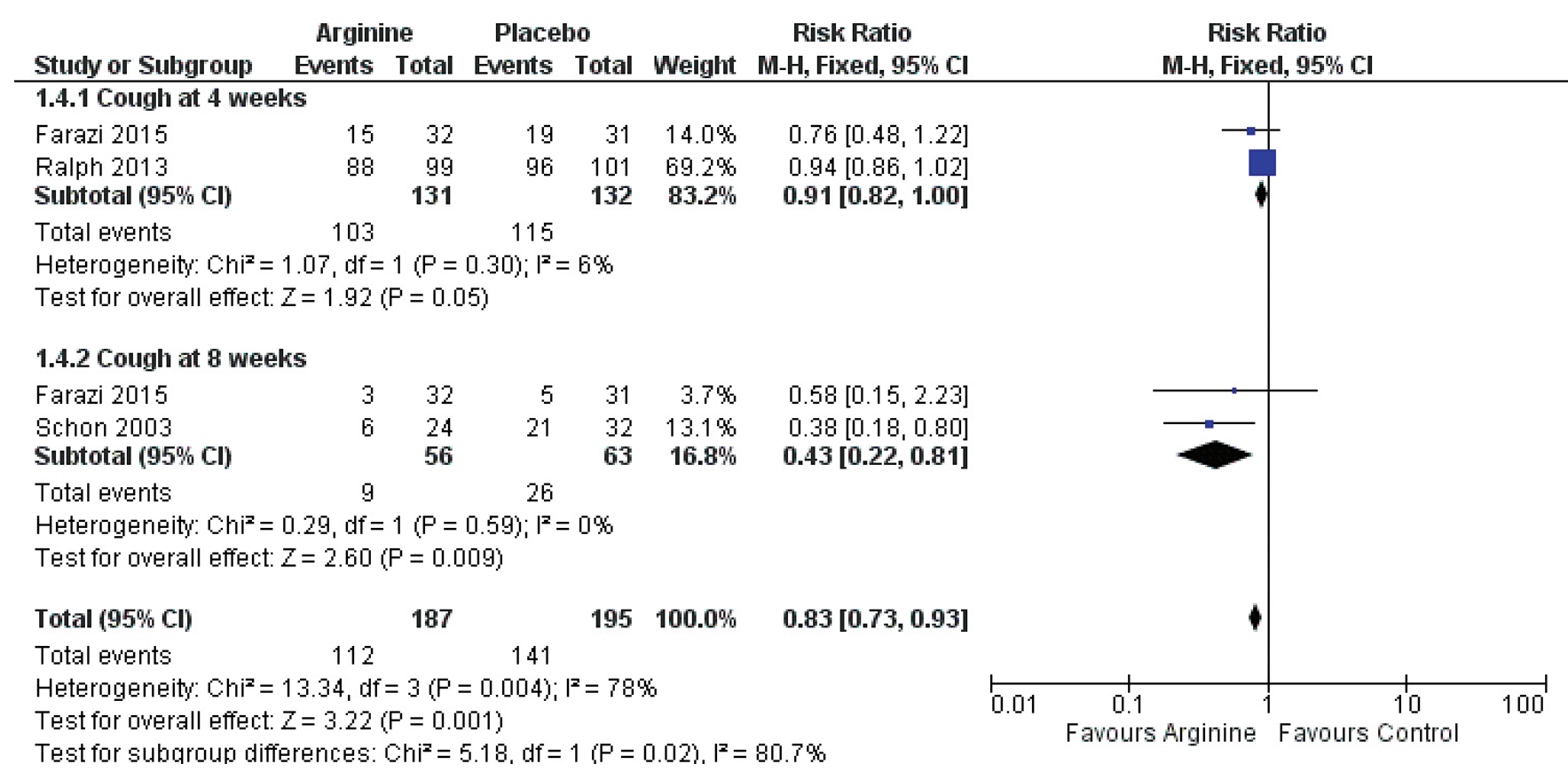

Figure 3. Comparison of arginine and placebo. Outcome 2 cough.

\section{Quality of the evidence}

The quality of evidence has been assessed using the Cochrane Risk of Bias Tool and is displayed in the characteristics of included studies and assessment of validity tables. 'Good' quality evidence implies that we could have some confidence in the result, but further research evidence might still be useful. 'Poor' quality reflects a low level of confidence in the result.

\section{Agreements and disagreements with other studies or reviews}

Arginine supplementation in adult patients with drugsensitive pulmonary tuberculosis has also been assessed by one previous Cochrane review. ${ }^{7}$ The study made by Sinclair in 2011 assessed one trial and found no significant increase in sputum smear conversion at eight weeks of treatment. They, however, reported a decrease in cough at second and eighth weeks of treatment. 


\section{CONCLUSION}

Arginine is not recommended to increase sputum conversion rates in patients with pulmonary tuberculosis but it may be helpful in improving cough reduction.

\section{Implications for practice}

Arginine supplementation may be useful in decreasing cough in patients with pulmonary tuberculosis. This may help in decreasing the infectivity of patients with the disease, given that pulmonary tuberculosis is primarily transmitted via airborne respiratory droplets.

\section{Implications for research}

The failure to demonstrate faster rates of sputum conversion with arginine supplementation does not imply that it is not effective. Further studies might still be done involving a higher dosage of arginine and a more adequate sample size. For other possible benefits, it would have been useful if some standardization of outcome measurements were made (for example, a tuberculosis response scoring system), to more completely assess treatment response.

\section{Limitations of the study}

The sample size may be too small to see a significant effect in terms of sputum conversion. Moreover, the differences in the dosing of the interventions in each study may account for differences in their results.

\section{Statement of Authorship}

All authors have approved the final version submitted.

\section{Author Disclosure}

All the authors declared no conflict of interest.

\section{Funding Source}

This paper was partially funded by the Philippine General Hospital and the authors.

\section{REFERENCES}

1. Sinclair D, Abba K, Grobler L, Sudarsanam TD. Nutritional supplements for people being treated for active tuberculosis (review). Cochrane Database Syst Rev. 2011; (11): CD006086. doi: 10.1002/14651858.CD006086.pub3.

2. Ralph AP, Waramori G, Pontororing GJ, et al. L-arginine and Vitamin $\mathrm{D}$ adjunctive therapies in pulmonary tuberculosis: a randomised, double-blind, placebo-controlled trial. PLoS ONE. 2013; 8(8):e70032.

3. Schon T, Elias D, Moges F, et al. Arginine as an adjuvant to chemotherapy improves clinical outcome in active tuberculosis. Eur Respir J. 2003; 21(3):483-8. doi: 10.1183/09031936.03.00090702.

4. Chan J, Tanaka K, Carroll D, Flynn J, Bloom BR. Effects of nitric oxide synthase inhibitors on murine infection with Mycobacterium tuberculosis. Infect Immun. 1995; 63(2):736-40.

5. Darwin KH, Ehrt S, Gutierrez-Ramos JC, Weich N, Nathan CF. The proteasome of Mycobacterium tuberculosis is required for resistance to nitric oxide. Science. 2003; 302(5652):1963-6.

6. Voskuil MI, Schnappinger D, Visconti KC, et al. Inhibition of respiration by nitric oxide induces a Mycobacterium tuberculosis dormancy program. J Exp Med. 2003; 198(5):705-13.

7. Farazi A, Shafaat O, Sofian M, Kahbazi M. Arginine adjunctive therapy in active tuberculosis. Tuberc Res Treat. 2015; 2015:205016.

8. Schon T, Idh J, Westman A, et al. Effects of a food supplement rich in arginine in patients with smear positive pulmonary tuberculosis: a randomized trial. Tuberculosis. 2011; 91(5):370-7.

\section{APPENDICES}

Appendix A. Prisma flow chart
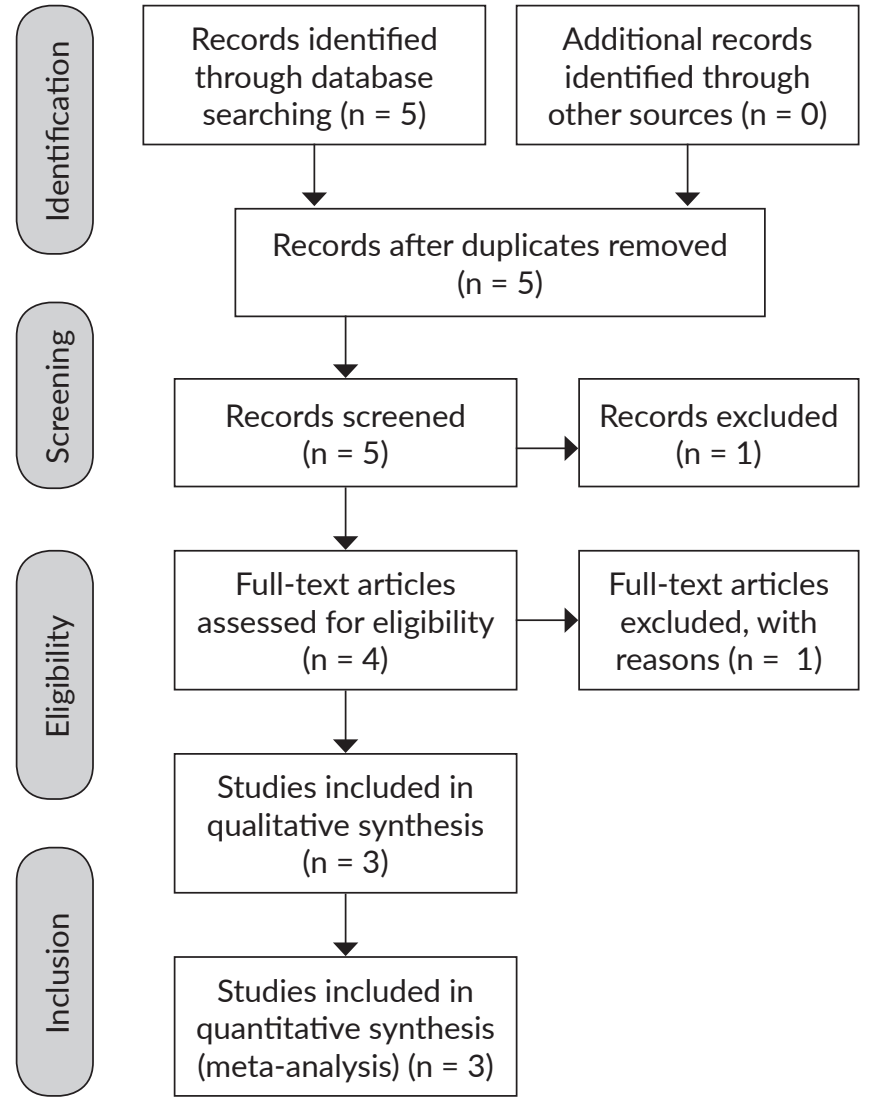
Appendix B. Characteristics of excluded studies

Schon 2011

\begin{tabular}{|c|c|}
\hline Methods & $\begin{array}{l}\text { Randomized controlled trial } \\
\text { Duration: Feb } 2004 \text { - Dec } 2006, \text { with a final follow up until August } 2007 \\
\text { Generation of allocation sequence: described as "randomized" } \\
\text { Allocation concealment: sealed individual envelopes } \\
\text { Blinded participants: no } \\
\text { Blinded providers: no } \\
\text { Blinded outcomes assessors: unclear } \\
\text { Inclusion of randomized participants in the analysis: } 173 / 180(96 \%) \text { of those who met the inclusion criteria }\end{array}$ \\
\hline Participants & $\begin{array}{l}\text { Number: } 180 \text { enrolled; outcomes presented for } 173 \\
\text { Inclusion criteria: age above } 15 \text { years old and acid fast bacilli (AFB) smear positive tuberculosis by microscopy as } \\
\text { recommended by the WHO for DOTS } \\
\text { Exclusion criteria: patients requiring hospital admission, peanut allergy, pregnancy, previous treatment for TB, clinical } \\
\text { signs or medical treatment indicating any concomitant disease such infectious diseases other than TB/HIV }\end{array}$ \\
\hline Interventions & $\begin{array}{l}\text { Group 1: } \\
\text { HRZE for } 2 \text { months } \\
\text { HE for } 6 \text { months } \\
\text { 30g of wheat crackers (daboqolo) }=0.1 \mathrm{~g} \text { arginine for } 4 \text { weeks } \\
\text { Group 2: } \\
\text { HRZE for } 2 \text { months } \\
\text { HE for } 6 \text { months } \\
\text { 30g of peanuts }=1 \mathrm{~g} \text { arginine for } 4 \text { weeks }\end{array}$ \\
\hline Outcomes & $\begin{array}{l}\text { 1. Cured, Not cured } \\
\text { 2. Smear conversion, weight gain }>10 \% \text {, cough, } S R(\mathrm{~mm} / \mathrm{h}) \text {, CXR improvement, Eno (ppb), uNO (microM) }\end{array}$ \\
\hline Notes & $\begin{array}{l}\text { Location: Ethiopia } \\
\text { Setting: Direct Observed Treatment Short-Course (DOTS) Clinic at Gondar University Hospital, Gondar, Ethiopia }\end{array}$ \\
\hline
\end{tabular}

Appendix C. Characteristics of included studies

Farazi 2015

\begin{tabular}{|c|c|}
\hline Methods & $\begin{array}{l}\text { Randomized controlled trial } \\
\text { Duration: December } 2012-\text { May } 2014 \\
\text { Generation of allocation sequence: described as "randomized" } \\
\text { Allocation concealment: sealed envelopes } \\
\text { Blinded participants: yes } \\
\text { Blinded providers: yes } \\
\text { Blinded outcomes assessors: unclear } \\
\text { Inclusion of randomized participants in the analysis: } 63 / 68(93 \%) \text { of those who met the inclusion criteria }\end{array}$ \\
\hline Participants & $\begin{array}{l}\text { Number: } 68 \text { enrolled; outcomes presented for } 63 \\
\text { Inclusion criteria: age of } \geq 15 \text { years and smear-positive pulmonary TB, as recommended by the World Health } \\
\text { Organization (WHO) for DOTS } \\
\text { Exclusion criteria: hospitalization, pregnancy, clinical signs of any comorbidity (such as diabetes mellitus, malignancy, } \\
\text { hepatic or renal failure, HIV+, etc) according to physician's judgement and patient's medical documents, patients } \\
\text { who received L-arginine supplement during the past month, and allergic reactions to L-arginine }\end{array}$ \\
\hline Interventions & $\begin{array}{l}\text { Group 1: } \\
\text { Isoniazid, rifampicin, pyrazinamide, and ethambutol for } 2 \text { months } \\
\text { Isoniazid, ethambutol to } 6 \text { months } \\
\text { 1000mg pure L-arginine hydrochloride OD for } 30 \text { days } \\
\text { Group 2: } \\
\text { Isoniazid, rifampicin, pyrazinamide and ethambutol for } 2 \text { months } \\
\text { Isoniazid, ethambutol to } 6 \text { months } \\
\text { Placebo with } 1000 \mathrm{mg} \text { of sugar OD for } 30 \text { days }\end{array}$ \\
\hline Outcomes & $\begin{array}{l}\text { 1. Final treatment success, sputum conversion, weight gain, and clinical symptoms after one and two months were } \\
\text { considered as primary outcomes } \\
\text { 2. Secondary outcomes were ESR, CRP, and Hg }\end{array}$ \\
\hline Notes & $\begin{array}{l}\text { Location: Iran } \\
\text { Setting: DOTS clinics in Markazi province }\end{array}$ \\
\hline
\end{tabular}


Ralph 2013

\begin{tabular}{|c|c|}
\hline Methods & $\begin{array}{l}\text { Randomized factorial trial } \\
\text { Duration: June } 12,2008 \text { - February } 22,2010 \\
\text { Generation of allocation sequence: described as "randomized" } \\
\text { Allocation concealment: opaque envelope } \\
\text { Blinded participants: yes } \\
\text { Blinded providers: yes } \\
\text { Blinded outcomes assessors: unclear } \\
\text { Inclusion of randomized participants in the analysis: } 155 / 200(78 \%) \text { of those who met the inclusion criteria }\end{array}$ \\
\hline Participants & $\begin{array}{l}\text { Number: } 200 \text { enrolled; outcomes presented for } 155 \\
\text { Inclusion criteria: sputum smear positive, >15 years, agreeing to stay in Timika for } 6 \text { months and providing written } \\
\text { informed consent } \\
\text { Exclusion criteria: pregnant, with hypercalcemia, not previously treated for TB }\end{array}$ \\
\hline Interventions & $\begin{array}{l}\text { Group 1: } \\
\text { HRZE daily for } 2 \text { months } \\
\text { HR thrice weekly for } 4 \text { months } \\
\text { A: Supplementary L arginine } 6 \mathrm{~g} \text { for } 8 \text { weeks, active cholecalciferol } 50,000 \mathrm{IU} \text { at baseline and on day } 28 \\
\text { B: L arginine } 6 \mathrm{~g} \text { for } 8 \text { weeks, placebo cholecalciferol } \\
\text { Group 2: } \\
\text { HRZE daily for } 2 \text { months } \\
\text { HR thrice weekly for } 4 \text { months } \\
\text { A: Placebo L arginine, active cholecalciferol } 50,000 \mathrm{IU} \text { at baseline and on day } 28 \\
\text { B: Placebo L arginine, Placebo Vitamin D }\end{array}$ \\
\hline Outcomes & $\begin{array}{l}\text { 1. Primary outcome measures were the proportion of participants with negative sputum culture on liquid medium at } \\
\text { Week 4, and a composite clinical severity score at Week } 8 \text {. The clinical score allocated points at Week } 8 \text { for \% change } \\
\text { in weight and FEV1, cough (worse or same, improved, ceased), and presence/absence of sputum and hemoptysis. } \\
\text { 2. Secondary outcomes were safety (death, hospitalization, hypercalcemia); sputum smear conversion time } \\
\text { ( } 2 \text { consecutive negative smears without a subsequent positive); change in 6-minute walk test, modified St George's } \\
\text { Respiratory Questionnaire, chest radiograph severity score, \%predicted forced expiratory volume in one second } \\
\text { (FEV1); and primary end points stratified by HIV status and ethnicity. }\end{array}$ \\
\hline Notes & $\begin{array}{l}\text { Location: Timika, Indonesia } \\
\text { Setting: Timika TB clinic }\end{array}$ \\
\hline
\end{tabular}

Schon 2003

\begin{tabular}{|c|l|}
\hline \multirow{3}{*}{ Methods } & $\begin{array}{l}\text { Randomized controlled trial } \\
\text { Duration: December 2000 - December 2001 } \\
\text { Generation of allocation sequence: described as "randomized" } \\
\text { Allocation concealment: sealed copy of treatment code } \\
\text { Blinded participants: yes } \\
\text { Blinded providers: yes } \\
\text { Blinded outcomes assessors: unclear } \\
\text { Inclusion of randomized participants in the analysis: 120/184 (65\%) of those who met the inclusion criteria }\end{array}$ \\
\hline Participants & $\begin{array}{l}\text { Number: 184 enrolled; outcomes presented for 120 } \\
\text { Inclusion criteria: age of 15-60 yrs and acid fast bacilli (AFB) smear-positive TB by microscopy, using Ziehl-Nielsen } \\
\text { staining, as recommended by the World Health Organization (WHO) for DOTS } \\
\text { Exclusion criteria: hospitalization, pregnancy or clinical signs of any concomitant disease, such as diabetes mellitus, } \\
\text { acute renal failure, or infectious diseases other than TB/HIV }\end{array}$ \\
\hline Interventions & $\begin{array}{l}\text { Group 1: } \\
\text { Isoniazid, pyrazinamide, rifampicin, and streptomycin or ethambutol for 2 months followed by isoniazid and } \\
\text { ethambutol for } 6 \text { months } \\
1 \text { g arginine for four weeks } \\
\text { Group 2: } \\
\text { Isoniazid, pyrazinamide, rifampicin, and streptomycin or ethambutol for 2 months followed by isoniazid and } \\
\text { ethambutol for } 6 \text { months } \\
1 \mathrm{~g} \text { placebo for four weeks }\end{array}$ \\
\hline Outcomes & $\begin{array}{l}\text { 1. Sputum conversion at Week } 8 \\
\text { 2. Cough at Weeks 2 and 8 }\end{array}$ \\
\hline Notes & $\begin{array}{l}\text { Location: Ethiopia } \\
\text { Setting: Direct Observed Treatment Short-Course (DOTS) Clinic at Gondar Hospital }\end{array}$ \\
\hline
\end{tabular}


Appendix D. Data extraction sheets

\begin{tabular}{|c|c|c|}
\hline Trial ID: Farazi 2015 & Extractor: Cheng, So & Year of Publication: 2015 \\
\hline \multicolumn{3}{|c|}{ Title: Arginine adjunctive therapy in active tuberculosis } \\
\hline \multicolumn{3}{|c|}{ Authors: Aliasghar Farazi, Omid Shafaat, Masoomeh Sofian, Manijeh Kahbazi } \\
\hline \multicolumn{3}{|c|}{$\begin{array}{l}\text { Citation: Farazi A, Shafaat O, Sofian M, Kahbazi M. Arginine Adjunctive Therapy in } \\
\text { 2015;2015:1-5 }\end{array}$} \\
\hline \multicolumn{3}{|c|}{ Participants } \\
\hline \multicolumn{3}{|c|}{$\begin{array}{l}\text { Inclusion criteria: } \\
\text { 1. New cases of smear positive TB (December 2012-May 2014, DOTS clinics in Markazi province) } \\
\text { 2. Age } \geq 15 y e a r s \text { old and smear positive TB (two or three positive morning sputum samples or one of three positive sample with a chest } \\
\text { x-ray and clinical symptoms suggestive of pulmonary TB) }\end{array}$} \\
\hline \multicolumn{3}{|c|}{$\begin{array}{l}\text { Exclusion criteria: } \\
\text { 1. Hospitalizations } \\
\text { 2. Pregnancy } \\
\text { 3. Clinical signs of any co-morbidity such as DM, malignancy hepatic or renal failure, HIV, etc according to the physician's judgment and } \\
\text { patient's medical documents } \\
\text { 4. Patients who received L-arginine supplementation in the past month } \\
\text { 5. Allergic reaction to L-arginine }\end{array}$} \\
\hline
\end{tabular}

Intervention

Experiment group:

1. Isoniazid, rifampicin, pyrazinamide and ethambutol for 2 months

2. Isoniazid, ethambutol to 6 months

3. $1000 \mathrm{mg}$ pure L-arginine hydrochloride OD for 30 days

Control/Comparison group:

1. Isoniazid, rifampicin, pyrazinamide, and ethambutol for 2 months

2. Isoniazid, ethambutol to 6 months

3. Placebo with $1000 \mathrm{mg}$ of sugar OD for 30 days

\begin{tabular}{|l|l|l|}
\hline \multicolumn{1}{|c|}{ Domain } & \multicolumn{1}{c|}{ Quality/Assessment/Risk of Bias Table } \\
\hline $\begin{array}{l}\text { Method of random sequence } \\
\text { generation (Selection bias) }\end{array}$ & Low risk & \multicolumn{1}{c|}{ Support for Judgment/ Description } \\
\hline $\begin{array}{l}\text { Method of allocation concealment } \\
\text { (Selection bias) }\end{array}$ & Low risk & $\begin{array}{l}\text { "Patients were randomly assigned to either the arginine group or } \\
\text { the placebo group. The randomization is 1:1 for the } 2 \text { groups and } \\
\text { was performed by using random number tables for the two assign } \\
\text { regimen" p.2 }\end{array}$ \\
\hline $\begin{array}{l}\text { Incomplete outcome data/Loss of } \\
\text { participant to follow up (Attrition bias) }\end{array}$ & $\begin{array}{l}\text { of the staff who was not directly involved in the study and a sealed } \\
\text { copy of the treatment code was kept by the project leader until all } \\
\text { data had been collected and analysed" p.2 }\end{array}$ \\
\hline $\begin{array}{l}\text { Blinding of participants and personnel } \\
\text { (Performance bias) }\end{array}$ & Low risk & Placebo-controlled trial \\
\hline $\begin{array}{l}\text { Blinding of outcome assessment } \\
\text { (Detection bias) }\end{array}$ & Unclear & No mention of blinding of outcome assessor, just assumed \\
\hline $\begin{array}{l}\text { Selective Reporting/Intention to treat } \\
\text { analysis (Reporting bias) }\end{array}$ & Low risk & \\
\hline Other bias & & \\
\hline
\end{tabular}


Outcomes

\begin{tabular}{|c|c|c|c|c|}
\hline \multirow{3}{*}{$\begin{array}{l}\text { Outcome measures } \\
\text { (Dichotomous) }\end{array}$} & \multicolumn{4}{|c|}{ Total number of participants } \\
\hline & \multicolumn{2}{|c|}{$\begin{array}{l}\text { Intervention group } \\
\qquad \mathrm{N}=32\end{array}$} & \multicolumn{2}{|c|}{$\begin{array}{c}\text { Control group } \\
\qquad N=31\end{array}$} \\
\hline & Events & Total & Events & Total \\
\hline \multicolumn{5}{|l|}{ Primary outcome(s) } \\
\hline Sputum conversion (smear negative) at 8 weeks & 31 & 32 & 27 & 31 \\
\hline \multicolumn{5}{|l|}{ Secondary outcome(s) } \\
\hline Constitutional symptoms at 4 weeks & 11 & & 19 & \\
\hline Constitutional symptoms at 8 weeks & 3 & & 8 & \\
\hline Cough at 4 weeks & 15 & & 19 & \\
\hline Cough at 8 weeks & 3 & & 5 & \\
\hline $\mathrm{BMI}<18.5$ at 4 weeks & 4 & & 11 & \\
\hline $\mathrm{BMI}<18.5$ at 8 weeks & 1 & & 6 & \\
\hline Positive sputum smear at 4 weeks & 14 & & 18 & \\
\hline Anemia at 4 weeks & 6 & & 12 & \\
\hline Anemia at 8 weeks & 2 & & 7 & \\
\hline Increasing ESR at 4 weeks & 25 & & 26 & \\
\hline Increasing ESR at 8 weeks & 11 & & 15 & \\
\hline Increasing CRP at 4 weeks & 8 & & 16 & \\
\hline Increasing CRP at 8 weeks & 2 & & 6 & \\
\hline Final treatment success & 32 & & 31 & \\
\hline
\end{tabular}

Trial ID: NCT00677339

Extractor: Cheng, So

Year of publication: 2013

Title: L-arginine and vitamin D adjunctive therapies in pulmonary tuberculosis: a randomised, double-blind, placebo-controlled trial

Authors: Anna P. Ralph, Govert Waramori, Gysje J. Pontororing, Enny Kenangalem, Andri Wiguna, Emiliana Tjitra, Sandjaja, Dina B. Lolong, Tsin W. Yeo, Mark D. Chatfield, Retno K. Soemanto, Ivan Bastian, Richard Lumb, Graeme P. Maguire, John Eisman, Ric N. Price, Peter S. Morries, Paul M. Kelly, Nicholas M. Anstey

Citation: Ralph AP, Waramori G, Pontororing GJ, Kenangalem E, Wiguna A, Tjitra E, et al. L-arginine and Vitamin D Adjunctive Therapies in Pulmonary Tuberculosis: A Randomised, Double-Blind, Placebo-Controlled Trial. PLoS ONE. 2013;8(8)

\section{Participants}

Inclusion criteria:

1. Sputum smear positive, $>15$ yo, not pregnant, without hypercalcemia (ionized calcium $\leq 1.32 \mathrm{mmol} / \mathrm{L}$ ), not previously treated for TB (p2) Exclusion criteria:

1. Participants with protocol violations or poor adherence were excluded (p5)

\section{Intervention}

Experiment group: Directly-observed anti-TB therapy (weight-dosed rifampicin, isoniazid, pyrazinamide, ethambutol daily $\times 2$ months, then rifampicin, isoniazid thrice weekly $x 4$ months) with either of the ff:

1. Supplementary active L-arginine $6 \mathrm{~g}$ daily for 8 weeks + active cholecalciferol $50000 \mathrm{IU}$ at baseline and on day 28

2. Active L-arginine + placebo cholecalciferol

3. Placebo L-arginine + active cholecalciferol

Control/Comparison group: Directly-observed anti-TB therapy (weight-dosed rifampicin, isoniazid, pyrazinamide, ethambutol daily $\times 2$ months, then rifampicin, isoniazid thrice weekly $\times 4$ months) with:

1. Placebo L-arginine + placebo cholecalciferol 
Quality/Assessment/Risk of Bias Table

\begin{tabular}{|c|c|c|}
\hline Domain & $\begin{array}{c}\text { Judgment } \\
\text { Low risk/High risk/Unclear }\end{array}$ & Support for judgment/ description \\
\hline $\begin{array}{l}\text { Method of random sequence } \\
\text { generation (Selection bias) }\end{array}$ & Low risk & $\begin{array}{l}\text { A block random allocation sequence stratified by ethnicity } \\
\text { was generated and remained concealed from all investigations } \\
\text { throughout the study (p3) }\end{array}$ \\
\hline $\begin{array}{l}\text { Method of allocation concealment } \\
\text { (Selection bias) }\end{array}$ & Low risk & $\begin{array}{l}\text { Independent assistants prepared study medication packs, labelling } \\
\text { them with a code corresponding to the randomisation sequence. } \\
\text { Participants were assigned the next sequential code, and dispensed } \\
\text { an opaque envelope containing the study medications. (p3) }\end{array}$ \\
\hline $\begin{array}{l}\text { Incomplete outcome data/Loss of } \\
\text { participant to follow up (Attrition bias) }\end{array}$ & High risk & \\
\hline $\begin{array}{l}\text { Blinding of participants and personnel } \\
\text { (Performance bias) }\end{array}$ & Low risk & This study was a double-blind factorial 2x2 design (p3) \\
\hline $\begin{array}{l}\text { Blinding of outcome assessment } \\
\text { (Detection bias) }\end{array}$ & Unclear & \\
\hline $\begin{array}{l}\text { Selective reporting/Intention to treat } \\
\text { analysis (Reporting bias) }\end{array}$ & Low risk & $\begin{array}{l}\text { Outcomes were analysed according to the arm to which the } \\
\text { participant was originally designed (p5) } \\
\text { In modified intention-to-treat analyses, participants with protocol } \\
\text { violations or poor adherence were excluded (p5) }\end{array}$ \\
\hline Other bias & & \\
\hline
\end{tabular}

Outcomes

\begin{tabular}{|c|c|c|c|c|}
\hline \multirow{3}{*}{$\begin{array}{l}\text { Outcome measures } \\
\text { (Dichotomous) }\end{array}$} & \multicolumn{4}{|c|}{ Total number of participants $=\mathbf{2 0 0}$} \\
\hline & \multicolumn{2}{|c|}{$\begin{array}{c}\text { Intervention group } \\
\text { Arms } A B(\text { Arginine } \pm \text { Vitamin } D) \text { : } \\
N=99\end{array}$} & \multicolumn{2}{|c|}{$\begin{array}{c}\text { Control group } \\
\text { Arms } C D(\text { No Arginine } \pm \text { Vitamin } D) \\
N=101\end{array}$} \\
\hline & Events & Total & Events & Total \\
\hline \multicolumn{5}{|l|}{ Primary outcomes } \\
\hline Culture negative at week 4 & $48 / 76(63.2 \%)$ & & $48 / 79(60.8 \%)$ & \\
\hline$<5 \%$ weight gain & $49(57 \%)$ & & $49(52 \%)$ & \\
\hline $5.0-9.9 \%$ weight gain & $22(26 \%)$ & & $26(27 \%)$ & \\
\hline$\geq 10 \%$ weight gain & $15(17 \%)$ & & $20(21 \%)$ & \\
\hline$\geq 10 \%$ fall in FEV1 & $4(5 \%)$ & & $13(14 \%)$ & \\
\hline$<10 \%$ fall or $<10 \%$ improvement & $44(55 \%)$ & & $50(55 \%)$ & \\
\hline$\geq 10 \%$ FEV1 improvement & $32(40 \%)$ & & $28(31 \%)$ & \\
\hline Worse/same cough & $6(7 \%)$ & & $9(10 \%)$ & \\
\hline Improved cough & $69(80 \%)$ & & $77(85 \%)$ & \\
\hline Ceased cough & $11(13 \%)$ & & $5(6 \%)$ & \\
\hline Sputum present & $63(73 \%)$ & & $68(72 \%)$ & \\
\hline Hemoptysis present & $2(2 \%)$ & & $1(1 \%)$ & \\
\hline \multicolumn{5}{|l|}{ Secondary outcomes } \\
\hline Culture negative at week 8 & $44 / 56(79 \%)$ & & $53 / 67(79 \%)$ & \\
\hline HIV (-) & $27 / 36(75 \%)$ & & $42 / 55(76 \%)$ & \\
\hline $\mathrm{HIV}(+)$ & $8 / 9$ (89\%) & & $5 / 5(100 \%)$ & \\
\hline Time to smear negativity: Median weeks (IQR) & $4(2-8)$ & & $5(2-8)$ & \\
\hline Death & $1 \%$ & & $1 \%$ & \\
\hline Hospitalization & $3 \%$ & & $2 \%$ & \\
\hline Mild hypercalcemia (1.33-1.39 mmol/L) & $12 \%$ & & $14 \%$ & \\
\hline Mod hypercalcemia (1.40-1.49 mmol/L) & $0 \%$ & & $3 \%$ & \\
\hline Severe hypercalcemia ( $\geq 1.33-1.39 \mathrm{mmol} / \mathrm{L})$ & $0 \%$ & & $0 \%$ & \\
\hline Nausea & $33 \%$ & & $34 \%$ & \\
\hline Vomiting & $21 \%$ & & $14 \%$ & \\
\hline CNS symptom (headache, dizziness, delirium) & $51 \%$ & & $56 \%$ & \\
\hline Itch & $43 \%$ & & $44 \%$ & \\
\hline Rash & $21 \%$ & & $27 \%$ & \\
\hline Arthralgia & $59 \%$ & & $59 \%$ & \\
\hline
\end{tabular}


Trial ID:

Extractor: Cheng, So

Year of publication: 2003

Title: Arginine as an adjuvant to chemotherapy improves clinical outcome in active tuberculosis

Authors: T. Schon, D. Elias, F. Moges, E. Melese, T. Tessema, O. Stendahl, S. Britton, T. Sundqvist

Citation Schon T, Elias D, Moges F, et al. Arginine as an adjuvant to chemotherapy improves clinical outcome in active tuberculosis. Eur Respir

J 2003;21:483-488 doi: 10.1183/09031936.03.00090702

Participants

Inclusion criteria:

1. Age of 15-60 yrs and acid fast bacilli (AFB) smear-positive TB by microscopy, using Ziehl-Nielsen staining, as recommended by the World Health Organization (WHO) for DOTS (p484)

Exclusion criteria:

1. Hospitalisation, pregnancy or clinical signs of any concomitant disease, such as diabetes mellitus, acute renal failure, or infectious diseases other than TB/HIV (p484)

Intervention

Experiment Group: isoniazid, pyrazinamide, rifampicin and streptomycin or ethambutol during the intensive phase of 2 months followed by isoniazid and ethambutol for 6 months.

1. Supplementation with $1 \mathrm{~g}$ arginine daily, administered orally for 4 weeks.

Control/Comparison group: isoniazid, pyrazinamide, rifampicin and streptomycin or ethambutol during the intensive phase of 2 months followed by isoniazid and ethambutol for 6 months.

1. Supplementation with identical capsules of $1 \mathrm{~g}$ placebo (State Pharmacy of Sweden) daily, administered orally for 4 weeks.

Quality/Assessment/Risk of Bias Table

\begin{tabular}{|l|l|l|}
\hline \multicolumn{1}{|c|}{ Domain } & \multicolumn{1}{c|}{$\begin{array}{c}\text { Judgment } \\
\text { Low risk/High risk/Unclear }\end{array}$} & Support for judgment/ Description \\
\hline $\begin{array}{l}\text { Method of random sequence } \\
\text { generation (Selection bias) }\end{array}$ & Low risk & $\begin{array}{l}\text { A sealed copy of the treatment codewas kept by the project leader } \\
\text { until all data had been collected and analysed. }\end{array}$ \\
\hline $\begin{array}{l}\text { Method of allocation concealment } \\
\text { (Selection bias) }\end{array}$ & Low risk & $\begin{array}{l}\text { Protocol was by intention-to-treat but as the drop out rate was low } \\
\text { (4.2\%, five of 120) and equally distributed among groups, the authors } \\
\text { did not include these patients in the statistical analysis (p484) }\end{array}$ \\
\hline $\begin{array}{l}\text { Incomplete outcome data/Loss of } \\
\text { participant to follow up (Attrition bias) }\end{array}$ & Low risk & The study was double blinded \\
\hline $\begin{array}{l}\text { Blinding of participants and personnel } \\
\text { (Performance bias) }\end{array}$ & Low risk & Protocol was by intention-to-treat (p484) \\
\hline $\begin{array}{l}\text { Blinding of outcome assessment } \\
\text { (Detection bias) }\end{array}$ & Unclear & \\
\hline $\begin{array}{l}\text { Selective reporting/Intention to treat } \\
\text { analysis (Reporting bias) }\end{array}$ & Low risk & \\
\hline Other bias & & \\
\hline
\end{tabular}

Additional Information Requested

Notes

\begin{tabular}{|c|c|c|c|c|}
\hline \multicolumn{5}{|c|}{ Outcomes } \\
\hline \multirow{3}{*}{$\begin{array}{l}\text { Outcome Measures } \\
\text { (Dichotomous) }\end{array}$} & \multicolumn{4}{|c|}{ Total number of participants $=$} \\
\hline & \multicolumn{2}{|c|}{$\begin{array}{l}\text { Intervention Group } \\
\mathrm{N}=\end{array}$} & \multicolumn{2}{|c|}{$\begin{array}{c}\text { Control Group } \\
\mathrm{N}=\end{array}$} \\
\hline & Events & Total & Events & Total \\
\hline \multicolumn{5}{|l|}{ Primary outcome(s) } \\
\hline Sputum conversion at week 8 (HIV-/TB+) & 24 & 24 & 27 & 32 \\
\hline \multicolumn{5}{|l|}{ Secondary outcome(s) } \\
\hline Cough at week 2 (HIV-/TB+) & 16 & 24 & 30 & 32 \\
\hline Cough at week 8 (HIV-TB+) & 6 & 24 & 21 & 32 \\
\hline
\end{tabular}

